\title{
EDITORIAL
}

\section{What Truly Matters: Relationships and Primary Care}

\author{
Mark Marnocha, PbD \\ Department of Family Medicine, University of Wisconsin School of Medicine and Public Health, \\ Fox Valley Family Medicine Appleton, Wisconsin
}

Ann Fam Med 2009;7:196-197. DOI. 10.1370/afm.1004.

$\mathrm{T}$ his issue of the Annals of Family Medicine features 4 essays by noted family physician and author David Loxterkamp. Why should a primary care research journal devote its space to a series of essays? Perhaps because narrative may help discern the best future for family medicine. Or because relationships with compelling essays are akin to powerful human relationships. Or because we need vivid reminders of "the magic of hope."

Whereas trials, meta-analyses, and guidelines serve the appetite for good evidence, personal reflections satisfy another appetite. We hunger for writings that speak richly of past seasons' trials and tell of the radiant skein of relationships revealed under duress and in crisis. In such times as ours, research and empirical results are of value, but the voices of caregivers and patients may well articulate what the data will parse much later. These narratives renew what is essential, no matter the current state of the evidence, no matter the time in which we live. They are both timely and timeless, speaking of life-span relationships, of the mutual humanity of physician and patient, of the uneasy place of family medicine in systems torn asunder to obtain questionable benefits. The lessons are those that come clear only after years of experience, when we realize that change in patient behavior is not "orchestrated," but rather discerned through close listening. And such listening needs a place at the heart of family medicine and at the center of a medical home.

Conflicts of interest: none to report

\section{CORRESPONDING AUTHOR}

Mark Marnocha, $\mathrm{PhD}$

Department of Family Medicine

UW School of Medicine and Public Health

Fox Valley Family Medicine

Appleton, WI 54911

mark.marnocha@fammed.wisc.edu
Research has shown that the patient-physician relationship is a drug of sorts, ${ }^{2}$ with therapeutic effects for the patient. ${ }^{3-5}$ And sometimes side-effects for the physician. The essays in this issue have a continuous strand of counsel and advocacy for the physician engaged in relationship-centered care. Physicians who have befriended the emotional depth of engaged caring and have encountered the limits of intervention have much to teach. As Dr Paul Rousseau concluded, "...I now realize that as a physician I am merely a shepherd guiding others through this convoluted, confusing, and forever-changing thing called life. And in time, with time, things will be okay - they will be as they must." ${ }^{\prime \prime}$

David Loxterkamp has been among those at the forefront of the initiative to recreate a medical home for primary care. ${ }^{7}$ He has articulated the emotional basis for such a home ${ }^{8}$ the need for emotional ownership thereof, ${ }^{9}$ and that home's rightful place in its neighborhood. ${ }^{10,11}$ His work underscores the need for mutuality between family medicine and its communities in the particular context of the US health care system, which cries out for the very primary care that it disenfranchises. More than ever, patients need the relationship with a trusted guide in illness and health, even as family medicine suffers through decreasing numbers of resident applicants, more busywork, fewer colleagues, more clinical demands, and a reimbursement system that favors intervention over relationship. Goodson has observed that "medicine's generalist base is disappearing" 12 as a consequence of that reimbursement system, and the essays in this issue speak to what is in jeopardy, what must not be lost. Diverse tools may help build the medical home for primary care, but "the focus must stay on relationships...the centerpiece of family medicine." ${ }^{7}$

As these essays amply demonstrate, Dr Loxterkamp's life work is not his job or his writing or his medical practice. Rather, his vocation resides in a desire 
for and commitment to "honest conversation," 8 a means to discover how others are "ready to come alive." ${ }^{18}$ As a psychotherapist, I have been encouraged to see Carl Rogers' emphases on empathy, genuineness, and positive regard for our patients revived in the patient-centered approach and its associated research. Not only do our patients need to find ways to "come alive," our health system must also "dignify and promote human relationships ${ }^{\prime \prime}$ in a way that invites primary care physicians to come alive as well. Relationships in health care are both "gold mine and landmine," 2 and the physician seeks a precarious balance of detachment and engagement. In "The Old Duffers' Club,"13 we see a support group that is as much for the doctor as for his patients, all seeking companionship and guidance, working together to revive direction and purpose.

The Old Duffers also represent the practice of "slow medicine," 13,14 care that diverges from urgent episodic care and takes its time to negotiate what is best. For those patients who are aged, who have chronic unremitting illness, and who have social and medical limitations, care must proceed at a pace that invites negotiating, sharing vulnerabilities, and paying attention to small things. Such care invites self-disclosure and is thus more attuned to life as a patient lives it and less driven by impersonal guidelines and decisions. These observations about old duffers harken back to Pankratz and Kofoed's work ${ }^{15}$ on the care of geezers, inviting us with humor and emotional clarity to rediscover the inner life of relationships within the examination room. The narratives bring to life recent research on contributions of medical visit companions to the care of the sickest elders ${ }^{16}$ and on the predictive power of careful attention to subtle neurologic abnormalities. ${ }^{17}$ Successful care in terminal illness and during the final days and years of life should offer "some sign that there is shelter here, and restorative good will. And mindfulness of what matters most." 1

The lessons in these essays are indeed timeless and as timely as the most recent medical literature on relationships, policies, and evidence-based primary care. Mauksch et $\mathrm{al}^{18}$ assemble succinct evidence for the interpersonal conditions most conducive to primary care, finding best empirical support for building rapport, setting agendas, and paying attention to social and emotional clues. Loxtercamp's essays are wondrous illustrations of providing and honing those therapeutic communication tools in relationship-centered care. Let us teach and practice in this fashion, then consider the evidence critically, but come back again and again to these essays, which carry the truth of particulars and the wisdom of seasons. They are written by one of our most careful observers of the moments of healing, speaking as a steady and compassionate guide, urging us to value what matters most within that most wonderful and "ordinary brand of medicine, which is our primary care." 12

To read or post commentaries in response to this article, see it online at http://www.annfammed.org/cgi/content/full/7/3/196.

Key words: Family practice; physician-patient relations; humanism; empathy; patient-centered care; personal narratives

Submitted February 2, 2009; submitted, revised, February 10, 2009; accepted March 21, 2009.

\section{References}

1. Loxterkamp D. The headwaters of family medicine. BMJ. 2008;337: a2575.

2. Loxterkamp D. A change will do you good. Ann Fam Med. 2009; 7(3):261-263.

3. Baldwin SA, Wampold BE, Imel ZE. Untangling the alliance-outcome correlation: exploring the relative importance of therapist and patient variability in the alliance. J Consult Clin Psychol. 2007;75(6):842-852.

4. McKay KM, Imel ZE, Wampold BE. Psychiatrist effects in the psychopharmacological treatment of depression. J Affect Disord. 2006;92(2-3):287-290.

5. Wampold BE, Imel ZE, Minami T. The story of placebo effects in medicine: evidence in context. J Clin Psychol. 2007;63(4):379-390, discussion 405-408.

6. Rousseau P. Piece of my mind. Seventy-two hours. JAMA. 2008; 300(8):882-883.

7. Loxterkamp D, Kazal LA Jr. Changing horses midstream: the promise and prudence of practice redesign. Ann Fam Med. 2008;6(2): 167-170.

8. Loxterkamp D. Doctors' work: eulogy for my vocation. Ann Fam Med. 2009;7(3):267-268.

9. Loxterkamp D. The dream of home ownership. Ann Fam Med. 2009;7(3):264-266.

10. Loxterkamp D. Facing our morality: the virtue of a common life. JAMA. 1999;282(10):923-924.

11. Fisher ES. Building a medical neighborhood for the medical home. N Engl J Med. 2008;359(12):1202-1205.

12. Goodson JD. Unintended consequences of resource-based relative value scale reimbursement. JAMA. 2007;298(19):2308-2310.

13. Loxterkamp D. The old duffers' club. Ann Fam Med. 2009; $7(3): 269-272$.

14. McCullough D. My Mother, Your Mother: Embracing Slow Medicine, the Compassionate Approach to Caring for Your Aging Loved Ones. New York, NY: Harper Collins; 2008.

15. Pankratz L, Kofoed L. The assessment and treatment of geezers. JAMA. 1988;259(8):1228-1229.

16. Wolff JL, Roter DL. Hidden in plain sight: medical visit companions as a resource for vulnerable older adults. Arch Intern Med. 2008;168(13):1409-1415.

17. Inzitari M, Pozzi C, Ferrucci L, et al. Subtle neurological abnormalities as risk factors for cognitive and functional decline, cerebrovascular events, and mortality in older community-dwelling adults. Arch Intern Med. 2008;168(12):1270-1276.

18. Mauksch LB, Dugdale DC, Dodson S, Epstein R. Relationship, communication, and efficiency in the medical encounter: creating a clinical model from a literature review. Arch Intern Med. 2008;168(13):1387-1395. 